\title{
SISTEM INFORMASI GEOGRAFIS PERSEBARAN TEMPAT IBADAH DAN KAPASITASNYA BERDASARKAN JUMLAH PENDUDUK DI KOTA BANJARMASIN
}

\author{
Nur Alamsyah' ${ }^{1)}$, Wagino ${ }^{2)}$ \\ 1) Fakultas Teknologi Informasi \\ Universitas Islam Kalimantan Muhammad Arsyad Al Banjari Banjarmasin \\ Email : uniskalam@gmail.com \\ 2)Fakultas Teknologi Informasi \\ Universitas Islam Kalimantan Muhammad Arsyad Al Banjari Banjarmasin \\ Email : ginouniska@gmail.com
}

\begin{abstract}
ABSTRAK
Sistem Informasi Geografi adalah suatu sistem informasi yang digunakan untuk memasukkan, menyimpan, memanggil kembali, mengolah, menganalisa dan menghasilkan data bereferensi geografis atau geospatial, untuk mendukung pengambilan keputusan dalam suatu perencanaan.

Penelitian ini dilakukan untuk menganalisis persebaran tempat ibadah dan kapasitasnya berdasarkan jumlah penduduk berbasis Sistem Informasi Geografis dikota Banjarmasin di 5 Kecamatan yaitu Kecamatan Banjarmasin Barat, Kecamatan Banjarmasin Timur, Kecamatan Banjarmasin Utara, Kecamatan Banjarmasin Selatan dan Kecamatan Banjarmasin Tengah. Tujuan untuk membantu para pengambil keputusan khususnya Kemenag dalam memutuskan apakah suatu daerah boleh atau tidaknya mendirikan tempat ibadah sesuai dengan peraturan Bersama Menteri Agama dan Menteri Dalam Negeri no 9 dan 8 tahun 2006.

Metode yang digunakan dalam penelitian ini untuk mendapatkan dan mengelola data dengan cara observasi langsung dengan mengambil data tempat ibadah pada instansi terkait yaitu Kementrian Agama (Kemenag) Kota Banjarmasin, kemudian Peta Administrasi kota Banjaramasin dan Studi Literatur.

Dengan menggunakan SIG maka diharapkan akan lebih mudah bagi para pengambil keputusan untuk mengetahui lokasi tempat ibadah beserta informasi yang tersedia yang ada dikota Banjarmasin. Karena dengan adanya SIG, maka akan digambarkan pula letak atau lokasi dari tempat ibadah pada kondisi yang sesungguhnya dalam bentuk peta.
\end{abstract}

Kata Kunci : SIG. Tempat Ibadah, Kota Banjarmasin

\section{PENDAHULUAN}

Banjarmasin memiliki suku asli yang bernama Suku Banjar, selain suku banjar, Banjarmasin dihuni oleh beberapa suku yang datang dari berbagai pulau di Indonesia seperti Suku Jawa, Suku Madura, Suku Bukit, Suku Bugis, Suku Sunda, Suku Bakumpai, Suku Bandar, dan lain-lain. Mayoritas mata pencaharian penduduk kota Banjarmasin adalah dagang, tani, industri dan lain-lain.

Banjarmasin yang berdimensi lima diarahkan pembangunannya sebagai Kota Pemerintahan, Perdagangan, Pelabuhan, Industri dan Pariwisata.

Berdasarkan data BPS Kota Banjarmasin tahun 2017, Banjarmasin memiliki penduduk sebanyak 606.189 jiwa dengan kepadatan 
185.640 jiwa per $\mathrm{km}^{2}$. Dapat dilihat pada tabel dibawah ini:

\begin{tabular}{|c|c|c|c|c|}
\hline $\mathrm{Ne}$ & Kecamatan & $\begin{array}{l}\text { I. aas } \\
\left(\mathrm{km}^{\prime}\right)\end{array}$ & $\begin{array}{l}\text { Jumalah Penduduk } \\
\text { (jiwn) }\end{array}$ & $\begin{array}{l}\text { Kepaidatan } \\
\text { (jiwa/tan') }\end{array}$ \\
\hline 1 & Banjarmasin Selatan & 38.26 & 159.761 & 4.175 \\
\hline 2 & Banjarmasin Timur & 23.86 & 121.611 & 5.097 \\
\hline 3 & Banjarmasin Barat & 13,37 & 150.693 & 11.271 \\
\hline 4 & Banjarmasin Tengab & 11,66 & 95.206 & 8.165 \\
\hline 5 & Banjarmasin Ctara & 78,014 & 78.918 & 156932 \\
\hline & Jumblah & 165,164 & 606.189 & 185.640 \\
\hline
\end{tabular}

Sumber : Bps Kota Banjarmasin

Kota Banjarmasin yang selain banyak dikunjungi karena tempat tempat wisatanya juga dikenal akan ketaatan beribadah para penduduknya sehingga di kota Banjarmasin banyak terdapat tempat-tempat peribadatan seperti masjid, gereja, pura, vihara dan kelenteng.

Sarana peribadatan sangatlah penting untuk seseorang dalam meningkatkan hubungan spritual dengan Tuhan. Karena itu hampir disetiap lingkungan masyarakat terdapat tempat peribadatan. Di Banjarmasin pencarian tempat ibadah selama ini dilakukan dengan cara-cara manual seperti bertanya kepada orang-orang sekitar atau dengan cara menyusuri jalan-jalan atau dengan menggunakan peta. Dengan cara seperti itu banyak mengalami masalah-masalah terutama bagi pendatang karena mereka tidak mengetahui dimana posisi mereka berada.

\section{RUMUSAN MASALAH}

Sistem Informasi Geografi adalah suatu sistem informasi yang digunakan untuk memasukkan, menyimpan, memanggil kembali, mengolah, menganalisa dan menghasilkan data bereferensi geografis atau geospatial, untuk mendukung pengambilan keputusan dalam suatu perencanaan. Dengan menggunakan SIG maka diharapkan akan lebih mudah bagi para pengambil keputusan untuk mengetahui lokasi tempat ibadah beserta informasi yang tersedia yang ada di Banjarmasin. Karena dengan adanya SIG, maka akan digambarkan pula letak atau lokasi dari tempat ibadah pada kondisi yang sesungguhnya dalam bentuk peta Banjarmsin.

\section{TUJUAN PENELITIAN}

Penelitian ini dilakukan untuk menganalisis persebaran tempat ibadah dan kapasitasnya berdasarkan jumlah penduduk berbasis Sistem informasi Geografis.

\section{TARGET LUARAN DAN MANFAAT PENELITIAN}

Target Luaran pada penelitian ini adalah Sedangkan target luarannya adalah jurnal Nasional OJS (Open Jurnal System) Technologia dan sebagai bahan ajar untuk matakuliah Sistem Informasi Geografis.

Sedangkan manfaat dari penelitian adalah untuk mendukung pengambilan keputusan dalam suatu perencanaan. Dengan menggunakan SIG maka diharapkan akan lebih mudah bagi para pengambil keputusan untuk mengetahui lokasi tempat ibadah beserta informasi yang tersedia yang ada di Banjarmasin

\section{METODE PENELITIAN}

Metode yang digunakan adalah dengan metode eksperimen, dengan tahapan penelitian sebagai berikut:

\section{Pengumpulan Data}

Teknik untuk memperoleh data dengan melakukan:

1) Observasi langsung dengan mengambil data tempat ibadah pada intansi terkait yaitu Kementrian Agama (Kemenag) Kota Banjarmasin.

2) Peta Administrasi kota Banjaramasin

3) Studi Literatur

Adapun beberapa hardware dan software yang digunakan adalah

Perangkat Keras (hardware)

1) Laptop Sony Vaio $11 \mathrm{Inc}$

2) Printer untuk mencetak laporan

3) Handphone Android termasuk GPS dan kamera untuk dokumentasi

Perangkat Lunak (software)

1) Microsoft Office 2013 
2) Tools Quantum GIS (QGis)

3) Google maps

\section{Lokasi penelitian}

Lokasi yang dijadikan objek penelitian berikut adalah Kota Banjarmasin terletak pada $3^{\circ} 15^{\prime}$ sampai $3^{\circ} 22^{\prime}$ Lintang Selatan dan $114^{\circ} 32^{\prime}$ Bujur Timur. Kota Banjarmasin berlokasi didaerah kuala sungai Martapura yang bermuara pada sisi timur Sungai Barito. Kota Banjarmasin terdiri atas 5 kecamatan, yaitu:

1. Banjarmasin Barat

2. Banjarmasin Selatan

3. Banjarmasin Tengah

4. Banjarmasin Timur

5. Banjarmasin Utara

\section{Pelaksanaan}

Secara garis besar proses dalam penelitian berikut terbagi atas tiga tahapan, yaitu :

\section{Proses Pra-pengolahan}

Proses pra-pengolahan data meliputi proses pengambilan data, koreksi geometrik dan proses input data.

\section{Proses pengambilan data}

\section{Proses pembuatan peta persebaran.}

Membuat peta persebaran tempat ibadah berdasarkan agama dan kapasitasnya. Dengan cara melakukan memilih pada Quantum GIS

Gambaran umum uraian metode penelitian tersebut dapat dilihat berupa diagram alir pada dbawah ini:

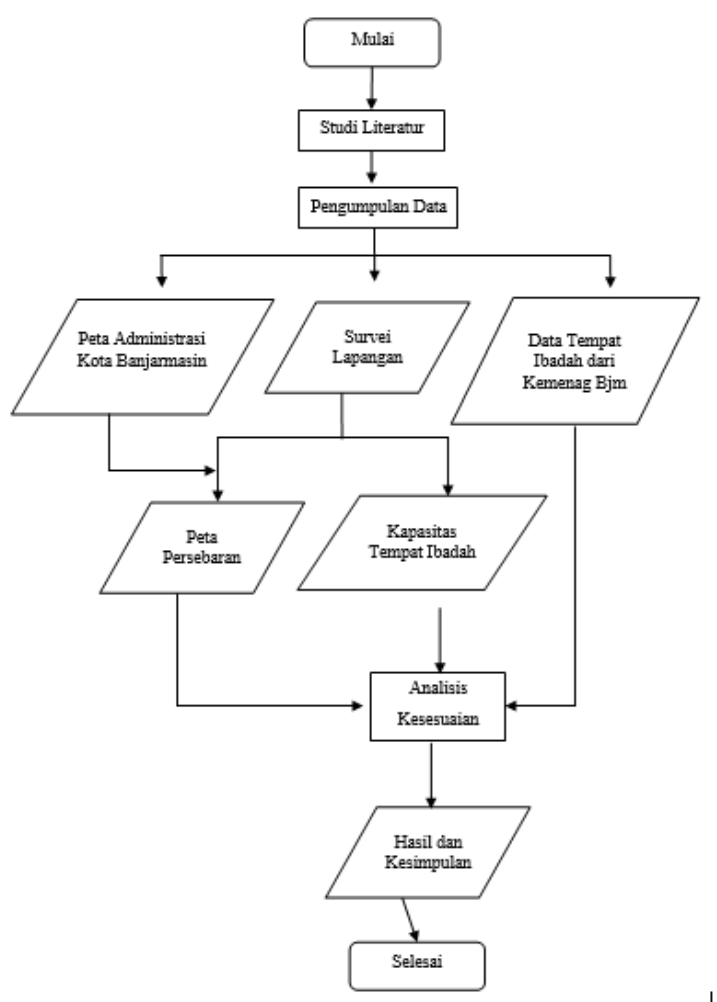

Diagram alir metode penelitian

\section{ANALISIS HASIL DAN PEMBAHASAN}

\section{Langkah-langkah penelitian}

langkah-langkah yang dilakukan untuk menyelesaikan penelitian seperti melakukan studi literatur, pengumpulan data, sampai langkah terakhir yakni penyusunan laporan. Langkah-langkah penelitian lebih jelasnya dapat dilihat pada Gambar dibawah ini:

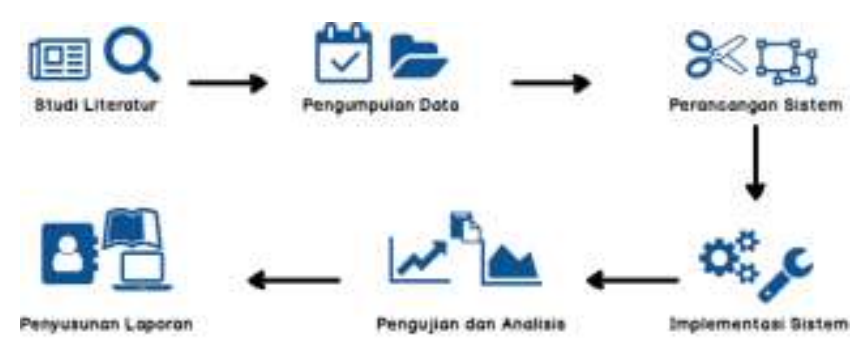

\section{Tahap Studi Literatur}

Pada tahap ini dilakukan pengumpulan teoriteori pendukung dari sistem yang dibuat seperti jurnal-jurnal terdahulu, buku-buku atau 
modul tentang SIG, Google Map API, dan PHP.

\section{Tahap pengumpulan data}

Pada tahap ini dilakukan proses pengumpulan data yang terdiri dari data tempat ibadah yang ada dikota Banjarmasin, jumlah penduduk kota Banjarmasin yang terdiri dari 5 kecamatan, peta kota Banjarmasin.

\section{Perancangan Sistem}

Dari data-data yang diperoleh kemudian diproses, selanjutnya dilakukan analisis dan perancangan system, perancangan database, analisis data spasial dan perancangan interface.

\section{Implementasi Sistem}

Pada tahap ini dilakukan proses implementasi dari rancangan system yang telah dibuat sebelumnya. Pada proses pembuatan system digunakan Bahasa-bahasa pemrograman seperti PHP, Javascript dan HTML.

\section{Pengujian dan Analisis}

Tahap ini dilakukan proses pengujian dan analisis system yang telah dibuat. Pengujian dan analisis dilakukan untuk mengetahui sejauh mana system yang dibuat pada penelitian ini dapat berfungsi sesuai dengan proses system yang diharapkan.

\section{Penyusunan Laporan}

Membuat dokumentasi dari semua tahapan proses yang telah dilakukan berupa laporan yang berisi tentang teori, hasil penelitian, serta hasil analisis dan kesimpulan.

\section{Hasil Aplikasi}

\section{Ujicoba input tempat ibadah}

Input data tempat ibadah hanya dapat dilakukan oleh user dengan hak akses sebagai super admin. Informasi data tempat ibadah yang harus dimasukkan kedalam sistem ini yang pertama adalah jenis tempat ibadah yang tampat pada google maps dbawah ini:

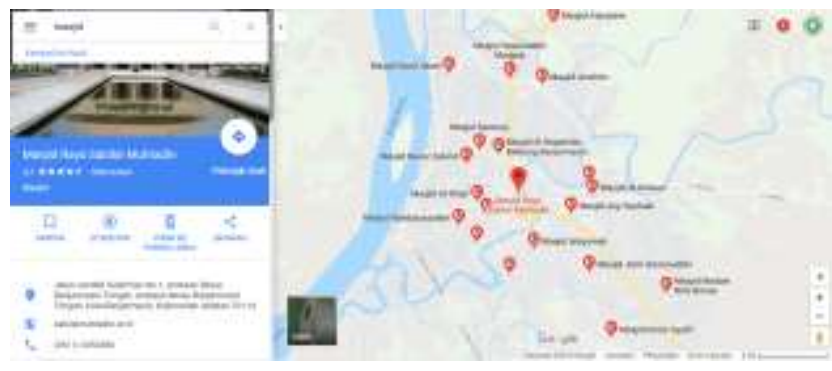

Gambar Jenis tempat ibadah dikota Banjarmasin

Setelah memasukkan jenis tempat ibadah, selanjutnya adalah memasukkan lokasi tempat ibadah, untuk memasukkan lokasi tempat ibadah dapat dilakukan dengan menempatkan marker pada peta, misalkan Masjid, maka akan tampil seperti dibawah ini:

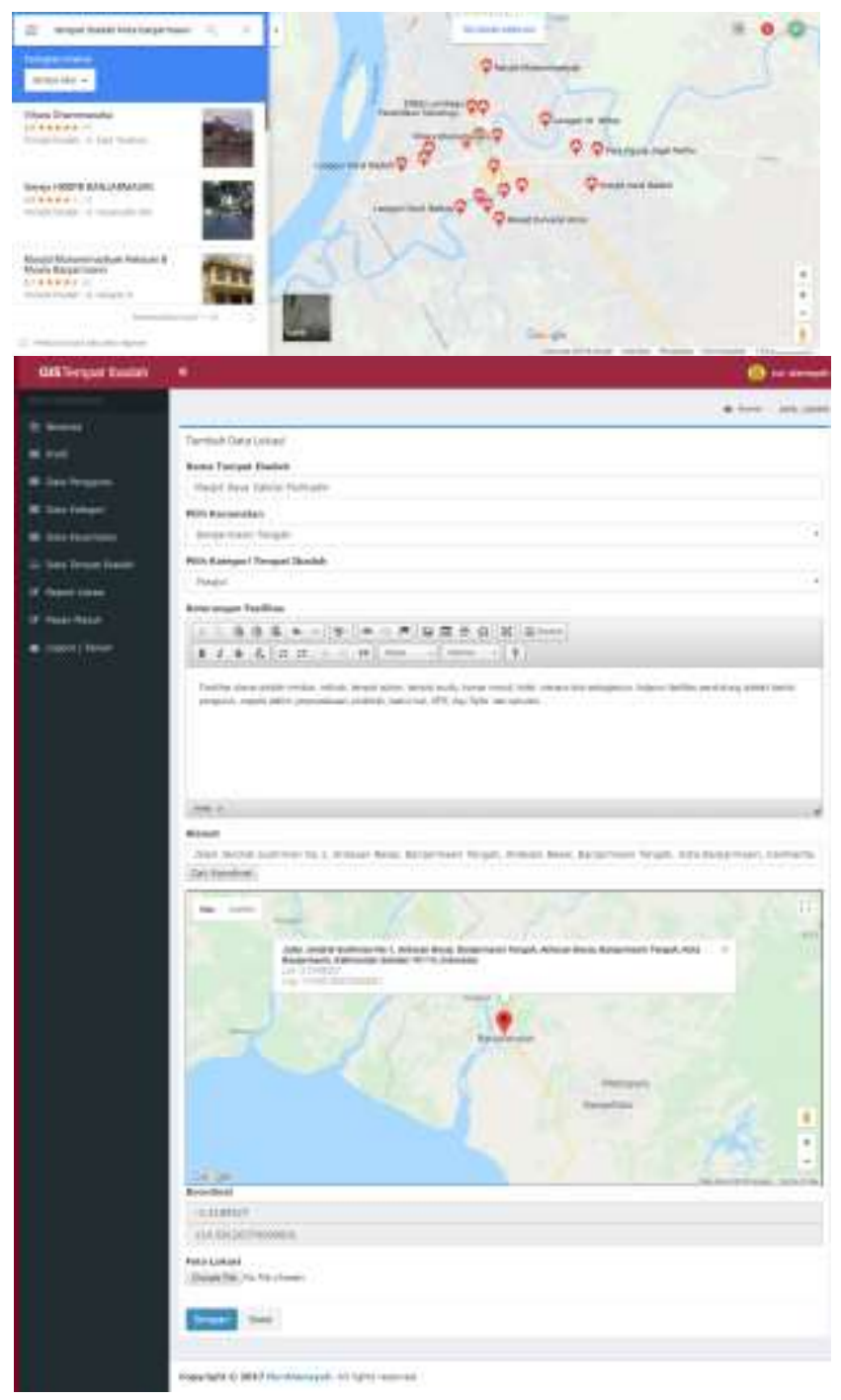


Gambar Memilih lokasi jenis tempat ibadah

\section{Hasil Tampilan Aplikasi persebaran tempat Ibadah}

Berikut hasil tampilan aplikasi yang telah dijalankan pada menu utama terdapat navigasi beranda, peta lokasi, tempat ibadah dan login.

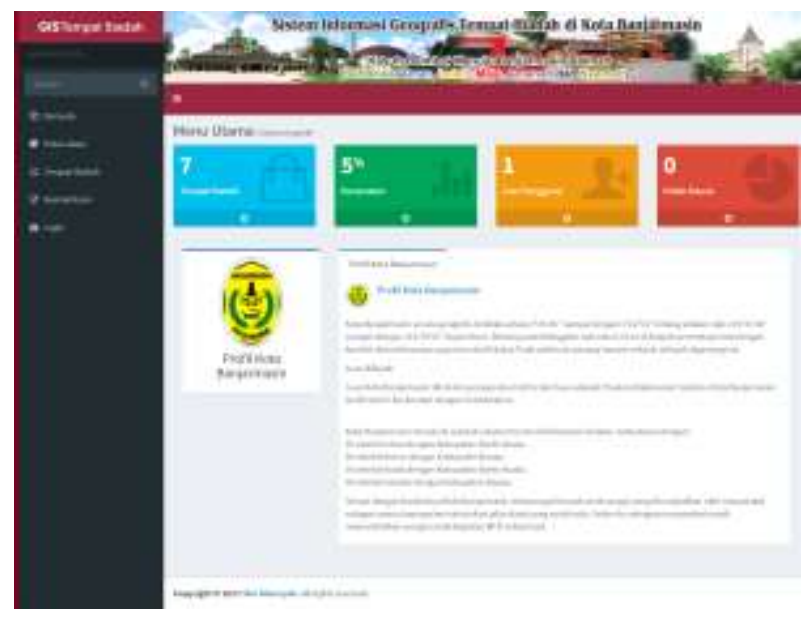

Gambar Menu Utama Aplikasi Tempat Ibadah

Pada halaman menu utama ditampilakan menu profil kota Banjarmasin yang menceritakan sejarah dan kondisi wilayah yang terbagi menjadi 5 kecamatan.

Kemudian pada halaman peta lokasi digambarkan peta kota Banjarmasin beserta detail lokasi tempat ibadah yang tersebar di 5 kecamatan yaitu:

\begin{tabular}{|c|c|c|c|c|c|c|}
\hline \multirow[b]{2}{*}{ No } & \multirow[b]{2}{*}{ Kecamatan } & \multicolumn{5}{|c|}{ Nama ' Tempat Thadah } \\
\hline & & Masjid & $\begin{array}{l}\text { Masholia } \\
\text { Canggar }\end{array}$ & Gereja & Vilara & Kleoteng \\
\hline I & $\begin{array}{l}\text { Banjarmasin } \\
\text { Selatan }\end{array}$ & 43 & 211 & 0 & 0 & 0 \\
\hline 2 & $\begin{array}{l}\text { Banjarmasia } \\
\text { Timaur }\end{array}$ & 41 & 172 & 0 & 0 & 0 \\
\hline 3 & $\begin{array}{l}\text { Banjarmasim } \\
\text { Barat }\end{array}$ & 32 & 170 & 0 & 0 & 0 \\
\hline 4 & $\begin{array}{l}\text { Banjarmasin } \\
\text { Tengah }\end{array}$ & 30 & 142 & 10 & 2 & 2 \\
\hline 5 & $\begin{array}{l}\text { Banjarmasia } \\
\text { Ctara }\end{array}$ & 37 & 151 & 0 & 0 & 0 \\
\hline & Jumlah & 183 & $8+6$ & 10 & 2 & 2 \\
\hline
\end{tabular}

\section{Sumber : Bps Kota Banjarmasin}

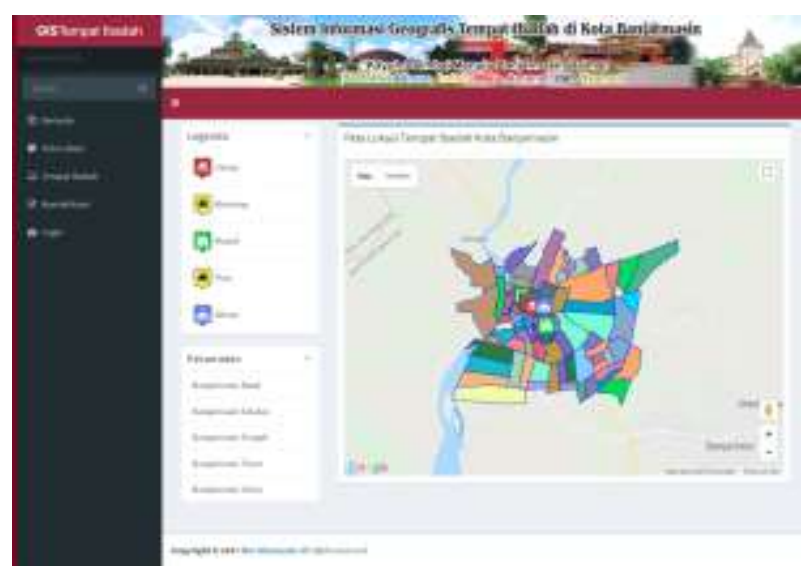

Pada sistem informasi ini hanya menampilkan data tempat ibadah di kota Banjarmasin dan jenis tempat ibadah yang ditampilkan adalah masjid, gereja, vihara, pura dan kelenteng. Selain itu, sistem informasi ini dibangun berbasis website dan menggunakan Google Maps API untuk menampilkan peta Kota banjarmasin.

\section{PENUTUP \\ Kesimpulan}

Berdasarkan hasil uji coba dan analisis yang telah dilakukan, didapatkan kesimpulan bahwa sistem informasi geografis ini dapat menampilkan informasi mengenai tempat ibadah secara lengkap sesuai lokasi di 5 kecamatan kota banjaramasin yaitu kecamatan Banjarmasin Selatan, Barat, Tengah, Timur, Utara dan disajikan pada peta dengan memberikan warna pada tiap tiap lokasi.

\begin{tabular}{|c|c|c|c|c|c|c|c|c|c|}
\hline \multirow[b]{2}{*}{ Ne } & \multicolumn{4}{|c|}{ 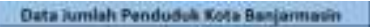 } & \multicolumn{5}{|c|}{ Niana Trmpat Haitsh } \\
\hline & Krecamatan & $\begin{array}{l}\text { Lass } \\
\text { (ane') }\end{array}$ & $\begin{array}{c}\text { dumbah } \\
\text { Proinetak } \\
\text { (Otwa) }\end{array}$ & 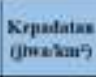 & stonpt & $\begin{array}{l}\text { Mtensulls } \\
\text { L.antzar }\end{array}$ & Erewa & Vhara & Kirairng \\
\hline 1 & $\begin{array}{l}\text { Baparmasil } \\
\text { Selataa }\end{array}$ & 38.26 & 159767 & 4.175 & a) & 211 & 7 & 2 & 0 \\
\hline 2 & $\begin{array}{l}\text { Baajarmasia } \\
\text { Tiney }\end{array}$ & $25 \times 6$ & 121611 & $\sin$ & 4I & 172 & 4 & 1 & 0 \\
\hline 3 & $\begin{array}{l}\text { Rajaranusin } \\
\text { Bazat } \\
\end{array}$ & 13,37 & 150693 & 11.271 & 52 & 170 & 8 & - & 0 \\
\hline 4 & $\begin{array}{l}\text { Banjarmasin } \\
\text { Trugah }\end{array}$ & IL66 & 95.206 & 8.165 & 30. & 142 & 11 & 3 & 2 \\
\hline 5 & $\begin{array}{l}\text { Bagarmasil } \\
\text { Ctan }\end{array}$ & 7804 & 78.918 & 196.952 & 37 & 154 & 1 & - & 0 \\
\hline & Jumtah & 165,2 & 606.159 & 185.6+10 & 183 & 846 & 31 & 6 & 2 \\
\hline
\end{tabular}

Berdasarkan tabel diatas dapat diketahui bahwa di kecamatan Banjarmasin Selatan dengan luas Wilayah $38,26 \mathrm{~km}^{2}$, jumlah penduduk 159,761 Jiwa memiliki 43 buah Masjid, 211 buah musholla atau langar, 7 buah gereja , 2 buah Vihara dan tidak memiliki Klenteng.

Untuk kecamatan Banjarmasin Timur dengan luas wilayah $23,86 \mathrm{~km}^{2}$, jumlah penduduk sebanyak 121,611 Jiwa, memiliki 41 Masjid, 172 Musholla atau Langgar, 4 buah Gereja dan 1 vihara.

Kemudian untuk kecamatan Banjarmasin Barat dengan luas wilayah 13,37 $\mathrm{km}^{2}$, jumlah penduduk sebanyak 150,693 Jiwa, memiliki 32 Masjid, 170 Musholla atau Langgar dan 8 buah Gereja. 
Untuk kecamatan Banjarmasin Tengah dengan luas wilayah 11,66 $\mathrm{km}^{2}$, jumlah penduduk sebanyak 95,206 Jiwa, memiliki 30 Masjid, 142 Musholla atau Langgar, 11 buah Gereja,3 vihara dan 2 klenteng.

Dan di kecamatan Banjarmasin Utara dengan luas wilayah $78,014 \mathrm{~km}^{2}$, jumlah penduduk sebanyak 78,918 Jiwa, memiliki 37 Masjid, 151 Musholla atau Langgar dan 1 buah Gereja.

Berdasarkan dari analisis data persebaran tempat ibadah di 5 kecamatan kota Banjarmasin dapat dijadikan pertimbangan untuk pengambilan keputusan dalam menentukan layak atau tidak untuk mendirikan tempat ibadah baru.

\section{Saran}

Untuk lebih meningkatkan kinerja dari sistem informasi geografis ini yang dapat dilakukan kedepannya adalah sebagai berikut :

1. Menambahkan detail informasi-informasi yang ditampilkan disetiap tempat ibadahnya.

2. Mengembangkan aplikasi berbasis mobile atau android

3. Dapat menerapkan aplikasi ini tidak hanya dikota Banjarmasin, melainkan provinsi dan dikota-kota lainnya.

4. Menerapkan aplikasi ini tidak hanya untuk menampilkan informasi tempat ibadah, tetapi juga informasi mengenai tempat-tempat penting lainnya seperti hotel, tempat wisata, restoran, pemerintahan, dan sebagainya.

\section{DAFTAR PUSTAKA}

Banjarmasin, B. k. (2015, April 1). banjarmasinkota.bps.go.id. Retrieved from https://banjarmasinkota.bps.go.i: https://banjarmasinkota.bps.go.id/ tanggal akses 19 Maret 2018 pukul 20.00 WITA getborneo. (2017, Juli 20). banjarmasin-kotaseribu-sungai. Retrieved from www.getborneo.com:

http://www.getborneo.com/banjarmasin- kota-seribu-sungai/ tanggal akses 2 Maret 2018 pukul 05.00 WITA

Hakim, A. R., \& Rengga Asmara, A. F. (Teknik Informatika Vol.1, No.1, 2012). Sistem Informasi Geografis Persebaran tempat Ibadah di Surabaya Menggunakan Google Maps API. www.jurnalpa.eepisits.edu, 1-8.

Indarto. (2013). Sistem Informasi Geografis. Jakarta: Graha Ilmu.

Kalsel, K. (2014, 25 September). datakeagamaan-kota-banjarmasin-tahun-

2014. Retrieved from https://kalsel.kemenag.go.id:

https://kalsel.kemenag.go.id/artikel/27454 /data-keagamaan-kota-banjarmasin-tahun2014?lang=ar tanggal akses 18 Maret 2018 pukul 10.15 WITA

Kalsel, k. (2016, Oktober 2). kesbangpolkemenag-dan-fkub-bahas-izin. Retrieved from http://kemenagbjm.blogspot.co.id: http://kemenagbjm.blogspot.co.id/2016/10 /kesbangpol-kemenag-dan-fkub-bahasizin.html tanggal akses 19 Maret 2018 pukul 20.00 WITA

Nursuci, S. R. (2013). Sistem Informasi Geografi Tempat Ibadah dikota Bogor berbasis WEB dengan menggunakan Quantum GIS. Jurnal Teknik Informatika, $1-5$.

picisan, R. (2015, Agustus 1). profil-kotabanjarmasin. Retrieved from www.wisatabanjarmasin.com:

http://www.wisatabanjarmasin.com/profilkota-banjarmasin/ tanggal akses 20 Maret 2018 pukul 05.15 WITA

PRAHASTA, E. (2015). Sistem Informasi Geografis Konsep Dasar. Jakarta: INFORMATIKA.

Ramadona, A. L., \& Kusnanto, H. (2010). Aplikasi Quantum GIS untuk Sistem Informasi Lingkungan. Yogyakarta: PSLH-UGM Press.

Widananto, K. A., Sudarsono, B., \& Wijaya, A. P. (2016). Analisis Persebaran Tempat Ibadah dan Kapasitasnya berdasarkan jumlah Penduduk berbasis SIG. Jurnal Geodesi UNDIP, 11-15. 